\title{
Forum
}

\section{Grazing Land Reform in New Zealand: Background, Mechanics, and Results Ann Brower}

Author is Lecturer of Public Policy, Environment, Society, and Design, Lincoln University, Christchurch, New Zealand.

\begin{abstract}
This article briefly reviews a complicated and politically explosive process of land reform on New Zealand's South Island. It presents the legal and administrative anatomy of the reform, and analyzes the results in light of the statutory goals. Comparing the results to the four goals reveals that the Crown has not defined its first goal and is meeting its goal of economic development, but has achieved only Pyrrhic victories for the conservation and recreation-related goals. The majority of the reformed land has been freed from pastoral constraints, but at a seemingly unnecessary cost to the public of NZ\$18.2 million. And on a key indicator of conservation, biodiversity protection, the Crown is failing to protect the most critical habitat while successfully protecting the scree and glacier, which require little protection. The New Zealand government has other policy tools available that might prove less expensive to the taxpayers and might yield conservation victories that are less Pyrrhic. Finally, the article concludes that a similar land reform policy idea is not likely to achieve legislative success elsewhere, as interest group opposition would be too intense.
\end{abstract}

\section{Resumen}

Este artículo revisa brevemente un proceso complicado y políticamente explosivo de reforma de la tierra en la Isla Sur de Nueva Zelanda. Se presenta la anatomía legal y administrativa de la reforma y analiza los resultados a la luz de las metas estatutarias. Comparando los resultados con las cuatro metas, se revela que la Corona no ha definido su primer meta, esta cumpliendo su meta de desarrollo económico, pero solo ha logrado victorias a muy alto pecio relacionadas a las metas de conservación y recreación. La mayoría de las tierras reformadas han sido liberadas de las restricciones pastoriles pero a un costo, aparentemente innecesario para el público, de NZ\$18.2 millones. En base a un indicador clave de conservación, la protección a la biodiversidad, la Corona esta fallando en proteger el hábitat mas critico, mientras que está protegiendo exitosamente los glaciares y rocallas, las cuales requieren poca protección. El gobierno de Nueva Zelanda tiene otras herramientas políticas disponibles, las cuales pudieran ser menos costosas para los contribuyentes y que pudieran rendir éxitos en la conservación, que serían más efectivos. Finalmente, este artículo concluye que la idea de una política similar de reforma de la tierra probablemente no logrará el éxito legislativo, así como la oposición del grupo de interés sería muy intensa.

Key Words: property rights, grazing permits, New Zealand, land reform, public lands, policy

\section{INTRODUCTION}

Slowly but surely, New Zealand is divesting its state-owned pastoral grazing lands. Farm by farm, it is renegotiating ownership of 2.4 million ha, or $10 \%$ of the country. In so doing, it is facilitating transformational landscape changes to the eastern slopes of the South Island's Southern Alps. In this article I describe the political goals and administrative mechanics of the reforms. I then compare the results to the goals and conduct a brief cost-benefit analysis using empirical results and goals as benchmarks. Finally, I offer a few policy prescriptions that might align the results more closely with the goals of land reform.

New Zealand is giving up on the multiple-use land management paradigm (Kirkland 1989) that dominates US public lands (Dana and Fairfax 1980). This grazing land reform is the last step toward separating commercial production from

This research was generously funded by a grant from IIE/Fulbright-New Zealand.

Correspondence: Dr Ann Brower, ESD, Lincoln University, PO Box 84, Christchurch, New Zealand. Email: Annbrower04@fulbrightweb.org

Manuscript received 18 August 2006; manuscript accepted 17 March 2007. conservation. In 1987 the Fourth Labour government corporatized and later privatized timber resources on state-owned forest land, disestablished the New Zealand Forest Service (Birchfield and Grant 1993; Brown and Valentine 1994; Hall 1997), and shifted authority over the state-owned forest land containing indigenous forest and conservation and recreation values to the newly formed Department of Conservation (hereafter DoC) (Bührs and Bartlett 1993; Memon 1993; Young 2004).

Managed by way of Crown pastoral leases, the high country pastoral estate is slowly undergoing a similar redistribution of uses and title. Some have suggested that other countries might consider shifting to this New Zealand model of forest management (Trummel 1994; Hall 1997; Gray 2003); the US Congress has considered a program to buy back grazing permits on federal land for conservation purposes (Steinbach and Thomas 2007). This article suggests that other countries should treat the New Zealand model with caution, and projects that a New Zealand-style policy idea is unlikely to succeed in other countries.

Currently the South Island high country pastoral estate is held by the Crown (New Zealand government) with certain use 
rights granted by way of perpetually renewable leases to runholders (pastoral lessees) to develop the pastoral (seasonal sheep grazing) resource. The Land Act of 1948 governs the present ownership patterns, while the Crown Pastoral Land Act of 1998 (CPLA) governs the redistribution of property rights, with the end goal of separating land uses: privatizing economically productive land and centralizing Crown authority over land with conservation and recreation values.

In this land reform, the government purchases grazing and occupation rights from each farmer for land with "significant inherent values" (CPLA §24(a)(3)) for conservation, recreation, heritage, or landscape (193000 ha to 30 June 2006). This land tends to be above $1000 \mathrm{~m}$ in elevation (Walker et al. in press) and less agriculturally productive than the lowlands. After the reform is complete, the government removes grazing from this high-altitude land, now administered by DoC, and establishes public conservation land and conservation parks in the former pastoral lease land.

The farmer also purchases clear title to land in his or her lease identified as "capable of economic use" (CPLA §24(a)(2)) (264 000 ha to 30 June 2006). By law, the more productive and commercially valuable land gets privatized, while the less productive (but perhaps more beautiful to conservationists and challenging to recreationists) gets transferred into public conservation land. After the reform, the farmer owns clear title (called freehold in New Zealand and fee-simple in the United States) to a portion of his or her original lease, without the restrictions of the lease that confined the lessee to extensive grazing. With clear title, he or she is free to apply for local District Council consent to develop, subdivide, irrigate, and build.

The leases range in size from 1000 to 76500 ha, with an average of 7000 ha (Cabinet Policy Committee 2005, p. 7). The pastoral estate supports about 2.8 million stock units, or about $4 \%$ of the total stock in New Zealand. Pastoral land produces a large portion of New Zealand's "extra fine" Merino wool. The land is quite varied in its pastoral productive capabilities, from the highly productive low lands, up to land above $2000 \mathrm{~m}$ in altitude with little to no productive capacity (Commissioner of Crown Lands 1994, p. 11).

In contrast to American grazing permits (Raymond 1997), pastoral leases create exclusive, legally enforceable, and compensable property rights. Pastoral leases encompass a tangled web of perceived rights, vested financial interests, and public and private claims on Crown-owned land. Slowly, on a run-by-run basis, the lessees are voluntarily entering negotiations with the Crown in which the bundle of property rights is redistributed such that each party (leaseholder and the Crown) ends up with clear title, and unencumbered rights to use the land as it wishes-whether it is commercial development by the farmer or creation of public conservation land by the government.

\section{HISTORY AND GOALS OF REFORMS}

In its current form, land reform developed through decades of political pressure by farming interests, conservation, and recreation interest groups, and the neoliberal administrative momentum for privatization in the 1980s and 1990s (Brower 2006). Finally in 1991, the Commissioner of Crown Lands directed agency staff to develop an administrative process of land tenure reform. Between 1991 and 1998, 34 leases completed the reform process.

In 1995 Denis Marshall, then the Minister of Lands and Conservation (two separate offices rarely held by one person, similar to the US offices of Secretary of Agriculture and of the Interior) proposed a bill to legalize the existing land tenure reform process. With some ado, Parliament signed the CPLA into law in 1998, with a party-line vote under a government led by the pro-farmer center-right National Party.

The CPLA aims to "establish a system for reviewing the tenure of Crown lands held under certain perpetually renewable leases" (Land Information New Zealand 1998, p. 4). It sets four goals for land tenure reform (CPLA §24):

1) To promote the management of reviewable land in a way that is ecologically sustainable;

2) subject to [above], enable reviewable land capable of economic use to be freed from the management constraints (direct and indirect) resulting from its tenure under reviewable instruments;

3) to enable the protection of the significant inherent values of reviewable land-by the creation of protective mechanisms, or (preferably) by the restoration of the land concerned to full Crown ownership and control;

4) subject to [above], to make easier the securing of public access to and enjoyment of reviewable land; and the freehold disposal of reviewable land.

\section{HOW DO LEASES AND REFORMS WORK?}

Pastoral leases are contractual agreements between the Crown as lessor and the leaseholder, granted by the Commissioner of Crown Lands under section 66 of the Land Act of 1948. The Crown has held title to the pastoral estate since the purchases from the Maori in the 1840s and 1850s, especially the Kemp's Deed purchase of 1848. The leased land is classified as "pastoral," or "land that is suitable or adaptable primarily for pastoral purposes only" (Land Act 1948, §51(1)(d); amended and repealed by CPLA §104).

The leases allow farmers to use the land for pastoral farming and personal residence. These use rights are vested property rights, compensable if revoked by the government, to use land in certain ways. If the farmer wishes to use the land for any other use, he or she must ask for consent for that use from the Commissioner of Crown Lands. In the reforms the Crown shifts some land into the Conservation Estate, hence extinguishing the lease and buying these use rights back from the lessee. The lessee obtains freehold title to the remainder, hence buying nonpastoral use rights previously withheld by the Crown.

Pastoral leases administer the distribution of usufructuary property rights among the leaseholder and the Crown, while the CPLA governs the redistribution of these use rights. If we consider the pastoral leases as a bundle of sticks, each representing a separate usufructuary property right (or use right), the farmer holds the rights to pasturage (though subject to stock limitations), occupation, trespass, and ownership of 
Table 1. Land reform legislative goals and indicators of success.

\begin{tabular}{|c|c|c|}
\hline Broad goals & Specific goals & Measures of success and cost \\
\hline \multirow[t]{4}{*}{ Resource production: Market/private sector } & 1. Ecologically sustainable management & None listed, goal not defined \\
\hline & 2. Land freed from constraints of pastoralism & a. No. hectares privatized \\
\hline & & b. Cost \\
\hline & & a. No. hectares shifted to DOC \\
\hline \multirow[t]{4}{*}{ Resource protection: Public ownership } & 3. Protection of conservation/recreation values by Crown & b. Cost \\
\hline & ownership & c. Conservation value of hectares \\
\hline & & a. Access easements provided \\
\hline & 4. Secure public access for recreation & b. Quality of access \\
\hline
\end{tabular}

physical "improvements" to land (Brookers Looseleaf Legal Service 1995, para. 11.23.02). The Crown holds the rights to soil, water, minerals, and all land uses other than pastoralism (Commissioner of Crown Lands 1994, p. 12). In legal terms the lessee holds grazing and occupation rights, and the Crown holds development rights.

The leases run for 33 years and are perpetually renewable (Land Act 1948, §66(2), amended and repealed by CPLA $\S 4(\mathrm{~b}))$, though a perpetually renewable lease is different from a lease in perpetuity, which is prohibited in common law (Brookers Looseleaf Legal Service 1995). Pastoral leases are also fully transferable by sale, gift, or inheritance, contingent on consent of the Commissioner (Land Act 1948, §93(1)). Hence the use rights that the lessee holds, he holds very strongly. But they are very tightly limited by law-to grazing and occupation. Any other uses require Crown permission.

Thus in the reforms, the Crown buys grazing and occupation rights and improvements from the lessee, and the lessee buys development rights from the Crown. This creates two relatively intact and separate bundles of property rights so that resource development and resource protection may proceed on separate plots of land, and by separate actors.

\section{ARE THE REFORMS WORKING? COMPARING ADMINISTRATIVE RESULTS TO POLITICAL GOALS}

Having reviewed goals, history, and legal and administrative mechanics of land reform, I now compare the results to date to the goals of the Act. Between 1992 and June 2006, 23\% of the original 340 leases had completed the reforms. A further $45 \%$ are now in the often protracted administrative process, and about one-third are abstaining from the voluntary reforms. With over two-thirds of lessees in or through the process, farmers are registering their approval and acknowledging that they stand to gain from the reforms.

With the reforms proceeding apace, it seems a good time to ask whether the results are meeting the stated goals listed in Tables 1 and 2. The Act neither defines nor prescribes indicators to measure progress toward its first goal, ecological sustainability. However, the other goals are easier to measure. As for the second goal of freeing land from pastoral constraints, the Crown has privatized 264000 ha (or 58\%). And to protect conservation values (third goal) and recreation access (fourth), the Crown has resumed grazing and occupancy rights to $42 \%$
(193000 ha) of the former leasehold estate. By law, this $42 \%$ is less capable of economic use than the newly privatized $58 \%$. Much of this $42 \%$ is above $1000 \mathrm{~m}$ in elevation, some covered with rock, scree, and snow (Walker et al. in press).

\section{Costs of Reforms: Property Rights and Prices in Pastoral Leases}

There are costs involved in the reforms. In a concurrent negotiation, each party buys out the other's property interest and use rights in the lease land, under CPLA §34. In total, the Crown has paid NZ\$18.2 million more than lessees have paid the Crown in "equity of exchange payments." In other words, grazing and occupation rights to the least productive land appear to carry NZ\$18.2 million higher value than freehold title and development rights to the most productive land.

This exchange of cash bears examination. By law, pastoral leases confer compensable, exclusive, and perpetually renewable rights to occupy and extensively graze the land. Leases do not confer development rights such as "subdivision," "building," or "commercial or industrial" uses (CPLA §6(a)(i-ii); replacing Land Act $\$ 66(7-8))$. Hence lessees have purchased development rights and clear title to $58 \%$ of the land. This $58 \%$ has been identified as more "capable of economic use" than the remainder. By this logic, one would expect any balance of cash would be owed to the Crown, not to the lessees.

For fee-simple title and development rights, the lessees have paid NZ\$18.5 million. In exchange for occupation and pastoral rights and improvements to $42 \%$ of the land, the Crown has paid NZ\$36.7 million to NZ\$18.2 million more than the lessees paid for development rights.

It is surprising for the Crown to lose money on net, while conveying development rights and title to the most developable land (Brower 2006). If development were of equal value to pastoral rights (NZ\$190/ha as estimated by Crown payments to lessees for grazing/occupation/improvements), then the lessees would owe the Crown NZ\$50 million instead of NZ\$18.5 million. Hence the net balance of cash would be $\$ 13$ million in favor of the Crown, instead of NZ\$18.2 million in favor of the lessees.

But in New Zealand development rights are not of equal value to grazing rights. Land used for nonpastoral uses is valued between 2.5 and 14 times more highly than land restricted to extensive pastoralism, as under pastoral lease (Stillman 2005). Given these findings, if farmers' payments reflected the empirically measured relationship between pastoral and development use rights, the lessees would owe the 
Table 2. Land reform legislative goals and measures of success to date.

\begin{tabular}{|c|c|c|}
\hline Specific goals & Indicators & Results \\
\hline 1. Ecologically sustainable management & None listed, goal not defined & \\
\hline \multirow[t]{3}{*}{ 2. Land freed from constraints of pastoralism } & a. No. hectares privatized & a. 264000 hectares $(58 \%)$ \\
\hline & b. Cost & b. NZ\$18.5 million (paid by farmers to Crown) \\
\hline & c. Production value & c. More productive land. \\
\hline \multirow{3}{*}{$\begin{array}{l}\text { 3. Protection of conservation/recreation values } \\
\text { by Crown ownership }\end{array}$} & a. No. hectares cleared of stock & a. 193000 hectares $(42 \%)$ \\
\hline & b. Cost & b. NZ\$36.7 (paid by Crown to farmers) \\
\hline & c. Conservation value of hectares & $\begin{array}{l}\text { c. Less productive land, of limited value for biodiversity/ } \\
\text { threatened species (Walker et al. in press). }\end{array}$ \\
\hline \multirow[t]{3}{*}{ 4. Secure public access for recreation } & a. Access easements & a. At least 1 access easement provided for each new \\
\hline & b. Quality of access & freehold parcel. \\
\hline & & $\begin{array}{l}\text { b. Recreation value difficult to quantify. Access easements } \\
\text { present, but access not always easy. }\end{array}$ \\
\hline
\end{tabular}

Crown between NZ\$125 million and NZ\$702 million for development rights and title to the portion being privatized. Given that land privatized through this land reform is advertised for sale at prices up to NZ\$6 million per hectare (see http://www.woodlotproperties.co.nz/Projects/properties. asp?ProjectID = 13, last accessed 10 February 2007), estimating that development rights are worth only 14 times pastoral rights seems conservative.

Hence this net loss to the Crown seems to value grazing rights as worth NZ\$18.2 million more than development rights, and stands in stark opposition to current research. Table 3 summarizes the predictions.

\section{Benefits of Reforms to Conservation and Recreation}

Finally, let us turn to the value of the higher-altitude land reserved for conservation and recreation (CPLA goals nos. 3 and 4). Land reform is often described as win-win (Cuddihy 2004; Mark et al. 2006), but what are the conservation and recreation interests winning? The land shifting from grazing to conservation is the least likely to be heavily grazed while under lease or developed after reforms, as the law mandates it be the least productive. Indeed, it is the newly privatized areas that contain the highest concentration of threatened species (Walker et al. in press). This is not entirely surprising as the land most productive for grazing is also often the richest in biodiversity (Scott et al. 2001; Knight 2002). Hence goals nos. 2 and 3 might well compete for the same land, but government officials indicate that privatizing land capable of economic use (goal no. 2) takes precedence over the latter conservation goal (Brower 2006; see also November 2006 North and South magazine pp. 43-45). While more land in parks may look like a victory for the conservation and recreation groups, ecological analysis of the land division indicates the victory is Pyrrhic for biodiversity protection (Walker et al. in press).

\section{POLICY ALTERNATIVES}

The New Zealand government could have chosen other tools to pursue its multiple goals of land use diversification on productive land, and conservation and recreation on land with ecological and aesthetic values. Exchanging property rights in this fashion is not the only available option:

1. Set a reserve price: Most simply, the Crown could set a reserve price for its compensation package, consisting of a combination of land and cash. This reserve price would set bounds for the negotiation, requiring Crown contractors to walk away from a deal if the price is too high.

2. Involve the courts: When policy is unclear, let the courts decide. This would maintain the current mechanism of redistributing property rights but change the administrative arrangements. Currently property rights are negotiated, valued, and redistributed in closed-door consultations between government contractors, the lessee, and perhaps a hired advocate for the lessee. The government

Table 3. Actual versus expected payments for property rights exchanged (NZ\$, millions).

\begin{tabular}{|c|c|c|c|}
\hline & Crown to Lessees & Lessees to Crown & Net to Crown \\
\hline Actual payments 1992-2006 & $\$ 36.7$ & $\$ 18.5$ & $-\$ 18.2$ \\
\hline \multicolumn{4}{|l|}{ Expected payments: } \\
\hline If value of development rights = value of pastoral rights & $\$ 37$ & $\$ 50$ & $\$ 13$ \\
\hline If value of development rights $=2.5 \times$ value of pastoral rights & $\$ 37$ & $\$ 125$ & $\$ 88$ \\
\hline If value of development rights $=14 \times$ value of pastoral rights & $\$ 37$ & $\$ 702$ & $\$ 665$ \\
\hline \multicolumn{4}{|c|}{ Expected payments if improvements constitute $50 \%$ of value of lessee's interest: } \\
\hline If value of development rights $=$ value of pastoral rights & $\$ 37$ & $\$ 25$ & $-\$ 12$ \\
\hline If value of development rights $=2.5 \times$ value of pastoral rights & $\$ 37$ & $\$ 63$ & $\$ 26$ \\
\hline If value of development rights $=14 \times$ value of pastoral rights & $\$ 37$ & $\$ 351$ & $\$ 314$ \\
\hline
\end{tabular}


contractor is simultaneously a negotiating party representing the Crown's vested interest and the referee in charge of the process. This option would place the judiciary, rather than a government agency and its contractors, in the role of referee in charge. It could make use of the existing Land Valuation Tribunal or Environment Court for this function (Brookers Looseleaf Legal Service 1995). This would enhance the role of the Court in determining the relative value of these property rights, rather than leave it to the negotiating powers of lessees and government contractors. It would also relieve the government agency of the conflicting roles of representing the Crown's interest while administering the process itself. But future Court costs might dwarf existing administrative costs.

3. Buy and sell: The Crown could buy the entire lease, reserve some for conservation, and sell the rest, as it did on Leatham Run. As the government would hold title free and clear of any lease obligations, identification of protected land would not be constrained by the lessee's interest. This would likely enhance the results for conservation, meaning a higher proportion of land identified as containing "significant inherent values" would survive the negotiation process to be transferred into public conservation land. After reserving some land for conservation, the government could sell the remaining land "capable of economic use" at auction. This would allow a market mechanism to determine the value of land development potential, rather than a government estimation of market prices and the ensuing private negotiation. It would also increase the likelihood of the Crown's capturing the value of the assets of which it is disposing. Though the initial cash outlay for the whole property purchase might be high, research on relative values of land in commercial development versus land in pastoral grazing suggests that the revenues generated at auction would be much higher (Stillman 2005). Eliminating lengthy negotiations would also drastically reduce administrative costs of the reform, which amount to NZ\$15 million to date.

4. Create reserves and amend Land Act: The Land Act gives ministers and the Governor General authority to create reserves on land under pastoral lease. Hence the government could create reserves on land sections with desired values, and create access easements across the pastoral land surrounding the reserves. The Land Act does not require compensation to the lessee for creation of the reserves themselves, but might require compensation for any value lost due to the easements or exclusion of sheep from the reserves. At the same time, Parliament could amend the Land Act to allow more uses on pastoral land-from viticulture to ski fields to golf courses-as desired by Parliamentarians and as permitted by the Commissioner of Crown Lands and the Resource Management Act. This option would not allow for any privatization and would likewise not extinguish the lease over land designated as reserves. But it would allow for protection of values, recreation access, and land use diversification. The cost would be administrative and any compensation owed to the lessee. That compensation could be determined by a court such as the Land Valuation Tribunal.

5. Buy some and amend: The government could buy out the lessee's interest in land deemed to be of conservation, recreation, or heritage value, and create publicly owned parks rather than reserves. As a condition of the government buying out the lessees' property rights, the government could amend and relax the Land Act's pastoral requirement, allowing for diversification but no subdivision. This would not allow any privatization, but would grant many of the property rights associated with freehold title and many of the rights in the nonpastoral bundle desired by lessees.

These are just a few options, briefly presented. Each would have proponents and opponents, as well as costs and benefits. It is not an exhaustive list but merely suggests that there are alternatives.

\section{IMPLICATIONS FOR OTHER COUNTRIES}

Though the New Zealand model of resource management has been suggested elsewhere, a similar grazing land reform policy idea is not likely to succeed in the United States. Indeed, reform ideas much more moderate than New Zealand's partial privatization have been suggested at least twice in the United States and quickly met fierce opposition from environmental interest groups.

From the 1960s through the 1980s, the Sagebrush Rebellion sought to transfer ownership of public grazing land from the federal government to the states (Cawley 1993). Though it was not an attempt to privatize public lands, it sought to devolve authority over land-to bring ownership closer to those who lived on and farmed the land. Despite decades of advocacy and high-ranking political support, the Sagebrush Rebellion met fierce resistance from environmental groups and ultimately failed to transfer ownership of grazing land.

By contrast, New Zealand environmental and recreation groups supported the land reform idea, with some reservations, largely because the property rights arrangements were different (Brower 2006). New Zealand pastoral leases grant the farmers trespass rights, meaning the farmer can exclude all recreationists from the lease, while American grazing permittees cannot (Raymond 1997). This meant that New Zealand environmental and recreation groups had something to gain from land reform and could report tangible victory to their members. But similar US groups opposed the Sagebrush Rebellion, as they saw no victories to report (Brower 2006).

Similarly, in February 2006 the Bush administration proposed privatizing up to 120000 ha (301355 acres) of the national forest system (http://www.fs.fed.us/land/staff/ spd_summary.html last accessed 16 January 2007), selling the land at auction to the highest bidder and using the projected US $\$ 800$ million in proceeds to boost funding for local schools (see 10 February 2006, Fresno Bee, p. B3). The proposed sale involved at most $0.16 \%$ of the entire National Forest System, or $0.009 \%$ of the total US landmass of about 900 million ha. Environmental groups immediately lined up to oppose the Bush initiative (see 11 February 2006, Sacramento Bee, p. A3). 
The Bush proposal was far smaller than New Zealand's land reform, involving less than $0.01 \%$ of the United States, instead of $10 \%$ of New Zealand, or $20 \%$ of the South Island. It was also more profitable than New Zealand's reform ideaproposing to net US\$800 million or about US\$7000 per hectare, instead of a net loss of US\$11 million. Finally, the beneficiaries would seem more politically appealing to interest groups: local schools instead of private farmers. But US environmental interest groups opposed both the Bush privatization proposal and the Sagebrush Rebellion, though the latter proposed no outright privatization. This suggests that a more radical New Zealand-style land reform policy idea is not likely to succeed in the US political arena.

\section{CONCLUSION}

This article has briefly reviewed a complicated and politically explosive process of land reform on New Zealand's South Island. It presents the anatomy of the reform and dissects the results. Comparing the results to legislative goals reveals that the Crown has not defined its first goal and is meeting its second goal, but has achieved only Pyrrhic victories for the conservation and recreation-related third and fourth goals. The majority of the reformed land has been freed from pastoral constraints, hence meeting the second goal, but at a seemingly unnecessary cost to the public of NZ\$18.2 million. On a key indicator of conservation, biodiversity protection, the Crown is failing to protect the most critical habitat while successfully protecting scree and high-altitude land that requires less protection. The New Zealand government has other policy tools available that might prove less expensive to the taxpayers and might yield conservation victories that are less Pyrrhic. Finally, the article concludes that New Zealand-style reforms are unlikely to enjoy legislative success in other countries because of strong political opposition from environmental interest groups.

\section{ACKNOWLEDGMENTS}

I thank Fulbright-New Zealand for supporting this research in many ways, two anonymous reviewers for their helpful comments, and academic colleagues in New Zealand and the United States for inspiration and suggestions.

\section{LITERATURE CITED}

BiRChField, R. J., AND I. F. GRant. 1993. Out of the woods: The restructuring and sale of New Zealand's state forests. Wellington, New Zealand: GP Publications. $250 \mathrm{p}$.
Brookers Looseleaf Legal Service. 1995. Land law. A.. Alston [ed.]. Wellington, New Zealand: Brookers.

BRower, A. 2006. Interest groups, vested interests, and the myth of apolitical administration: the politics of land tenure reform on the South Island of New Zealand [thesis]. Wellington, New Zealand: Fulbright-New Zealand.

Brown, C. L., AND J. Valentine. 1994. The process and implications of privatization for forestry institutions: focus on New Zealand. Unasylva: An international journal of forestry and forest industries 178 .

BüHRS, T., AND R. V. BARTLETt. 1993. Environmental policy in New Zealand: the politics of clean and green? Auckland, New Zealand: Oxford University Press. $192 \mathrm{p}$.

Cabinet Policy Committee. 2005. South island high country objectives. Wellington, New Zealand: Cabinet Office. $20 \mathrm{p}$.

CAwLEY, R. M. 1993. Federal land, western anger: the Sagebrush Rebellion and environmental politics. Lawrence, KS: University Press of Kansas. 195 p.

Commissioner of Crown Lands. 1994. The tenure of Crown pastoral land, the issues and options: a discussion paper. Wellington, New Zealand: Government of New Zealand.

Cuddihy, M. 2004. DOC's Strategy for the South Island high country. Primary Industry Management 7:22-24.

Dana, S. T., and S. K. Fairfax. 1980. Forest and range policy: Its development in the United States. 2nd ed. New York, NY: McGraw-Hill. 458 p.

GraY, J. A. 2003. Forest tenures and concession experience in Canada and selected other countries. In: Institutional changes in forest management in countries with transition economies: Problems and solutions; 25 February 2003. Moscow, Russia.

HaLL, O. F. 1997. New Zealand's privatization of forest lands: policy lessons for the United States and elsewhere? Forest Science 43:181-193.

KIRKLAND, A. 1989. The rise and fall of multiple use management in New Zealand. New Zealand Journal of Forestry 34.

KNIGHT, R. L. 2002. The ecology of ranching. In: R. L. Knight, W. Gilgert, and E. Marston [EDS.]. Ranching west of the 100th meridian. Washington, DC: Island Press. p. 123-144.

Land Information New Zealand. 1998. Crown Pastoral Land Act 1998 Registration Guidelines. Wellington, New Zealand: Government of New Zealand. 14 p.

Mark, A., K. Dickinson, and B. Patrick. 2006. Indigenous grassland protection in New Zealand. Frontiers in Ecology and the Environment 6(1):290-291.

Memon, P. A. 1993. Keeping New Zealand green: Recent environmental reforms. Dunedin, New Zealand: University of Otago Press. $173 \mathrm{p}$.

RAYMond, L. 1997. Viewpoint: are grazing rights on public lands a form of private property? Journal of Range Management 50:431-438.

Scott, J. M., R. J. F. AвbitT, and C. R. Groves. 2001. What are we protecting? Conservation Biology in Practice 2:18-19.

Steinbach, M. S., and J. W. Thomas. 2007. Potential outcomes and consequence of a proposed grazing permit buyout program. Rangeland Ecology \& Management 60(1):36-44.

Stillman, S. 2005. Examining changes in the value of rural land in New Zealand between 1989 and 2003. Wellington, New Zealand: Motu Economic and Public Policy Research. $42 \mathrm{p}$.

Trummel, C. 1994. Privatizing New Zealand's forests and managing public concern. Journal of Forestry 92:30-32.

Walker, S., R. Price, and R. T. Stephens. In press. An index of risk to biodiversity to measure conservation achieved by land reform in New Zealand. Conservation Biology.

Young, D. 2004. Our islands, our selves: A history of conservation in New Zealand. Dunedin, New Zealand: University of Otago Press. 298 p. 